\title{
Uji Aktivitas Antioksidan Kombinasi Ekstrak Sarang Semut ( Myrmecodia Pendans) dan Daun Sirsak (Annona muricata) dengan Metode DPPH (2,2-diphenyl-1-picrilhidrazyl)
}

\section{Antioxidants Activity of Myrmecodia pendans Extract Combine with Annona muricata Leaf Extract Using DPPH (2,2-diphenyl-1-picrilhidrazyl) Methode}

\author{
Wimpy ${ }^{1}$, Suharyanto ${ }^{2}$ \\ ${ }^{1}$ Akademi Analis Kesehatan Nasional Surakarta, Indonesia \\ ${ }^{2}$ Akademi Farmasi Nasional Surakarta,Indonesia
}

\section{INTISARI}

Radikal bebas adalah suatu senyawa atau molekul yang mengandung satu atau lebih elektron tidak berpasangan pada orbital luarnya sehingga menyebabkan senyawa tersebut sangat reaktif mencari pasangannya dengan cara menyerang dan mengikat elektron molekul yang berada di sekitarnya. Akibat kerja radikal bebas adalah gangguan fungsi sel, kerusakan struktur sel, bahkan mutasi.Antioksidan merupakan senyawa yang dapat menghambat oksigen reaktif dan radikal bebas dalam tubuh.Senyawa flavonoid di dalam daun sirsak dan sarang semut berperan sebagai anti oksidan. Tujuan dari penelitian ini adalah untuk menguji aktivitas antioksidan kombinasi ekstrak sarang semut (Myrmecodia Pendans) dan Daun Sirsak (Annona muricata) dengan metode DPPH (2,2-diphenyl-1-picrilhidrazyl). Penelitian ini dilakukan dengan desain analitik eksperimental.Tempat untuk mendapatkan ekstrak dan uji aktivitas antioksidan dilakukan di laboratorium Kimia Akademi Analis Kesehatan Nasional Surakarta.Penelitian dilakukan pada tahun 2014.

Hasil penelitian didapatkan, rendemen hasil ekstraksi teknik maserasi, semua fraksi terdeteksi adanya Alkaloid, flavonoid, saponin dan Tanin, fraksi air sarang semut mempunyai IC50sebesar 76,64 ppm sedang fraksi butanol sebesar 76,82 ppm, kombinasi ekstrak sarang semut dan ekstrak daun sirsak (1:1) mempunyai IC50 sebesar 71,09 ppm, fraksi air daun sirsak mempunyai IC50 73,48 ppm sedang fraksi butanol memiliki IC50 99,70 ppm sehingga fraksi air lebih baik dibandingkan fraksi butanol. Kombinasi ekstrak sarang semut dengan daun sirsak dengan perbandingan 1:1 memiliki aktifitas antioksidan lebih baik dari bentuk tunggalnya.

Keywords : sarang semut, daun sirsak, ekstraksi ultrasonic, IC50

\begin{abstract}
Free radicals are highly reactive molecules containing one or more unpaired electrons in its outer orbital Free radicals attackelectron binding molecules in the surrounding areas. Malfunctioning cells, damage cell structures, and even mutations are the effects of free radical. Antioxidants can inhibit reactive oxygen and free radicals in the human body. The compound flavonoid, which is contained in thesoursop's leaf and sarang semut act as
\end{abstract}


anti-oxidants. This researchaimsto test the antioxidant activity of the combinationof extractedsarang semut (Myrmecodia pendans) and Soursop's leaf (Annona muricata) with DPPH (2,2-diphenyl-1-picrilhidrazyl)method. This researchwas conducted byplantextractionSarangsemut and soursop's leafwithmaceration The results showed that ultrasonic extraction techniqueall fractions are detected such as alkaloids, flavonoids, saponins and tannins, water fraction of sarang semut has76.64 ppm IC50 and the butanol fractions has $76.82 \mathrm{ppm}$ IC50, the combination of extracted sarang semut and extractedsoursop's leaf (1: 1) have $71.09 \mathrm{ppm}$ IC50, the water fraction soursop leafhas 73.48 ppm IC50, and butanol fraction has 99.70 ppm so we can conclude that the water fraction of sarang semut is better than butanol fraction of sarang semut extract. The combination betweenextracted soursop'sleaf and extracted sarang semut with a ratio of 1: 1 has a better antioxidant activity than the singular.

Keywords : Myrmecodia pendans, soursop's leaf, Ultrasonic Extraction, IC50

\section{PENDAHULUAN}

Radikal bebas adalah suatu senyawa atau molekul yang mengandung satu atau lebih elektron tidak berpasangan pada orbital luarnya. Adanya elektron yang tidak berpasangan menyebabkan senyawa tersebut sangat reaktif mencari pasanganny dengan cara menyerang dan mengikat elektron molekul yang berada di sekitarnya. Akibat kerja radikal bebas adalah gangguan fungsi sel, kerusakan struktur sel, bahkan mutasi. Gangguan tersebut dapat memicu munculnya berbagai penyakit dan kanker (Winarsi, 2007). Untuk menangkal atau menghentikan aktivitas radikal bebas diperlukan elektron untuk berpasangan dengan elektron pada orbital terluar dari senyawa radikal bebas. Untuk melakukan peristiwa ini perlu adanya sumber atau agen pemberi elektrron. Zat antioksidan merupakan sumber elektron bebas karena pada senyawa antioksidan memiliki pasangan elektron bebas.

Antioksidan merupakan senyawa yang dapat menghambat oksigen reaktif dan radikal bebas dalam tubuh. Senyawa antioksidan ini akan menyerahkan satu atau lebih elektron kepada radikal bebas sehingga menjadi bentuk molekul yang normal kembali dan menghentikan berbagai kerusakan yang ditimbulkan (Dalimartha dan Soedibyo, 1999). Kemampuan suatu antioksidan untuk meredam radikal bebas dapat dinyatakan dalam aktivitas antioksidan sebagai parameternya. Semakin tinggi aktivitasnya maka radikal bebas semakin berkurang yang pada akhirnya dapat mengurangi resiko terkena kanker.

Daun sirsak secara empiris dapat bermanfaat sebagai antikanker dan antioksidan. Pada penelitian sebelumnya, ekstrak butanol daun sirsak (Anonna muricata) dapat memberikan aktivitas antioksidan dengan nilai IC50 52,4 $\mu \mathrm{g} / \mathrm{ml}$ (George, 2012).

Secara fitokimia, senyawa flavanoid merupakan senyawa yang berperan aktif sebagai antioksidan, disamping tanin atau alkaloid. Pada penelitian ini akan dilakukan ekstraksi daun sirsak untuk mengetahui aktifitas antioksidan yang terkandung di dalamnya.

\section{METODE PENELITIAN}

a. Persiapan sampel

Sampel berupa irisan umbi sarang semut dan daun sirsak yang telah dikeringkan. Ditimbang kurang lebih $1 \mathrm{~kg}$ simplisia sarang semut. Sekanjutnya dilakukan penggerusan menggunakan alat gerus listrik Dari penggerusan diperoleh serbuk sarang semut dan daun sirsak dengan ukuran tertentu.

\section{b.Maserasi}

Serbuk sarang semut dan daun sirsak masing-masing seberat 450 gram 
dimasukkan kedalam wadah kemudian ditambahkan 2 liter metanol, larutan dibiarkan selama 5 hari, sambil dilakukan pengadukan setiap hari.

\section{c.Partisi Sampel}

Maserat metanol dilakukan ekstraksi menggunakan butanol air 1:1. Dari kedua partisi ini didapatkan ekstrak kental butanol dan air.

\section{d.Pengujian Aktivitas Antioksidan}

Uji Aktivitas ekstrak Sarang Semut dilakukan menggunakan Radikal bebas DPPH. Pada uji ini sejumlah konsentrasi ekstrak Sarang Semut dicampur dengan larutan DPPH. Banyaknya senyawa DPPH yang diikat ekstrak sarang diketahui dengan mengukur serapannya menggunakan spektrofotometer.

\section{e. Uji Fitokimia}

Uji ini merupakan uji kualitatif, digunakan untuk menentukan kandungan bahan aktif dalam tumbuhan.Uji
Fitokimia dilakukan dengan metode Skrining Fitokimia dengan menggunakan reagen Dragendrof, $\mathrm{FeCl} 3$ dan lain-lain. Uji ini dilakuikan untuk menguji adanya Alkaloid, Flavonoid dan tannin dalam tumbuhan Sarang Semut dan daun sirsak(Harbone, 1987)

\section{HASIL DAN PEMBAHASAN}

a. Hasil Ekstraksi Sarang Semut dan Daun Sirsak

Hasil ekstraksi Sarangsemut dan daun Sirsakdisajikan pada tabel I dan tabel II. Dari hasil maserasi Sarangsemut diperoleh rendemen rata-rata sebesar 18,97 \%. Sedangkan dari ekstraksi daun sirsak diperoleh rendemen sebesar 15,77 $\%$.

Tabel I. Hasil ekstraksi Sarangsemut

\begin{tabular}{cccc}
\hline $\begin{array}{c}\text { Berat Cwn } \\
\text { Kosong }\end{array}$ & $\begin{array}{c}\text { Berat Cwn } \\
+ \text { ekstrak }\end{array}$ & Brt Ekstrak & Rendemen \\
\hline $\begin{array}{c}71,0 \text { gram } \\
\text { (A) }\end{array}$ & 100,1 gram & 29,1 gram & $19,4 \%$ \\
70,0 gram & 97,75 gram & 27,75 gram & $18,5 \%$ \\
$\begin{array}{c}\text { (B) } \\
68,75\end{array}$ & 97,25 gram & 28,5 gram & $19 \%$ \\
gram $(\mathrm{C})$ & & & \\
\hline
\end{tabular}

Tabel II. Hasil ekstraksi Daun Sirsak

\begin{tabular}{cccc}
\hline $\begin{array}{c}\text { Brt Cwn } \\
\text { Ksong }\end{array}$ & $\begin{array}{c}\text { Brt Cwn } \\
+ \text { samp }\end{array}$ & Brt Samp & Rendemen \\
\hline $\begin{array}{c}\text { 70,0 gram } \\
\text { (A) }\end{array}$ & 93,25 gram & 23,25 gram & $15,5 \%$ \\
$\begin{array}{l}\text { 68,75 } \\
\text { gram (B) }\end{array}$ & 93,5 gram & 24,75 gram & $16,5 \%$ \\
$\begin{array}{c}71,0 \text { gram } \\
(\text { C })\end{array}$ & 93,95 gram & 22,95 gram & $15,3 \%$ \\
\hline
\end{tabular}

\section{b. Hasil Fraksinasi}

Hasil pemisahan dari tiap pelarut dipekatkan hingga diperoleh ekstrak kental. Dari pemekatan didapatkan randemen ekstrak sarang semut fraksi air sebesar $12,53 \%$ b/b, randemen ekstrak sarang semut fraksi butanol sebesar
9,48\% $\%^{\mathrm{b}} / \mathrm{b}$, randemen ekstrak daun sirsak fraksi air sebesar $14.11 \%$ b/b. dan randemen ekstrak daun sirsak fraksi butanol sebesar $10.25 \% \mathrm{~b} / \mathrm{b}$. Hasil fraksinasi sarangsemut dan daun sirsak disajikan pada tabel III dan tabel IV. 
Tabel III.Hasil Fraksinasi Sarangsemut

\begin{tabular}{ccccc}
\hline Fraksi & Brt Cwn Ksong & Brt Cwn +samp & Brt Samp & Rendemen \\
\hline Air & 68,83 & 8,62 & 18,79 & $12,53 \%$ \\
Butanol & 70,83 & 56,61 & 14,22 & $9,48 \%$ \\
\hline
\end{tabular}

Tabel IV.Hasil Fraksinasi Daun Sirsak

\begin{tabular}{ccccc}
\hline Fraksi & Brt Cwn Ksong & Brt Cwn + samp & Brt Samp & Rendemen \\
\hline Air & 62.97 gram & 84.14 gram & 21.17 gram & $14.11 \%$ \\
Butanol & 64.14 gram & 79.52 gram & 15.38 & $10,25 \%$ \\
\hline
\end{tabular}

\section{c. Uji Aktifitas Antioksidan Sarang}

\section{Semut}

Berdasarkan pengujian diperoleh persamaan regresi linier ekstrak etanol sarang semut fraksi air $\mathrm{Y}=0,4052 \mathrm{x}+$ 18,872. Sehingga dapat diketahui nilai $\mathrm{IC}_{50}$ ekstrak sarang semut fraksi air sebesar 76,64 ppm.
Pengujian aktivitas antioksidan juga dilakukan pada ekstrak sarang semut fraksi butanol Berdasarkan pengujian diperoleh persamaan $\mathrm{Y}=0.36445 \mathrm{x}+$ 22.065, sehingga nilai $\mathrm{IC}_{50}$ ekstrak sarang semut fraksi butanol dapat diketahui yaitu sebesar 76,82 ppm.

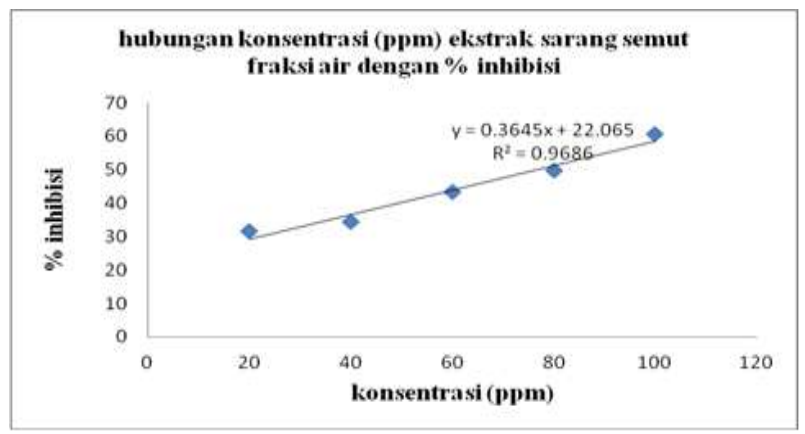

Gambar 1. Hubungan Konsentrasi Ekstrak Sarang Semut Fraksi Air dengan Persen Inhibisi

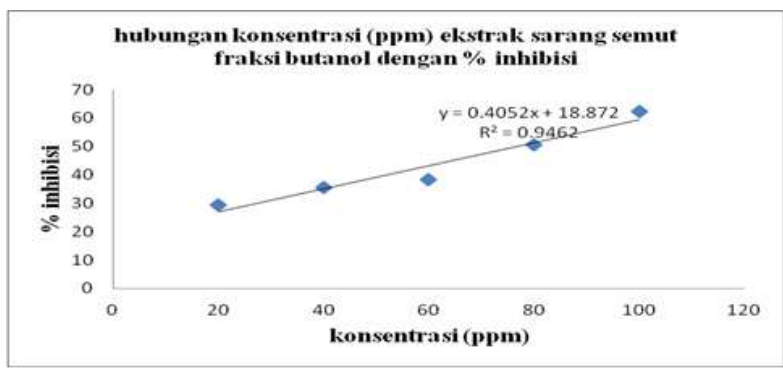

Gambar 2. Hubungan Konsentrasi Ekstrak Sarang Semut Fraksi Butanol dengan Persen Inhibisi

Berdasarkan kurva diatas dapat diamati bahwa konsentrasi berbanding lurus dengan persen inhibisi.Ekstrak sarang semut fraksi air memiliki nilai $\mathrm{IC}_{50}$ 76,64 ppm, sedangkan fraksi butanol
76,82 ppm. Ekstrak sarang semut fraksi air memiliki $\mathrm{IC}_{50}$ lebih kecil dibandingkan ekstrak sarang semut fraksi butanol, maka aktivitas antioksidan fraksi air lebih baik. 


\section{d. Uji Aktifitas Antioksidan Daun}

Sirsak

Dari gambar 3. dapat dilihat persamaan regresi linier ekstrak daun sirsak fraksi air $\mathrm{Y}=0,34945 \mathrm{x}+24,319$.
Sehingga dapat diketahui nilai $\mathrm{IC}_{50}$ ekstrak daun sirsak fraksi air yaitu sebesar 73,48 ppm. Pengujian aktivitas antioksidan juga dilakukan pada ekstrak daun sirsak fraksi butanol.

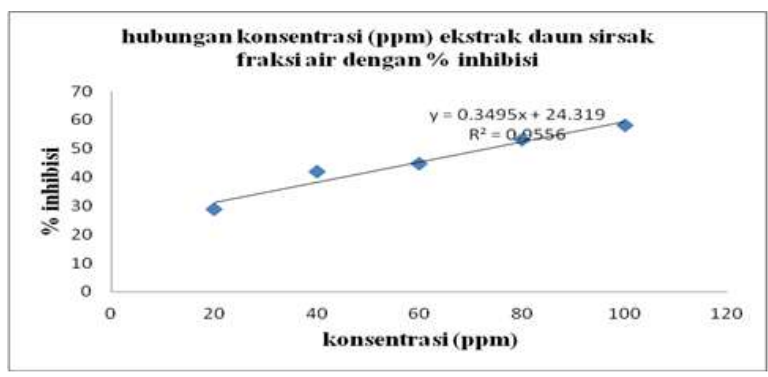

Gambar 3. Hubungan Konsentrasi Ekstrak Daun Sirsak Fraksi Air dengan Persen Inhibisi.

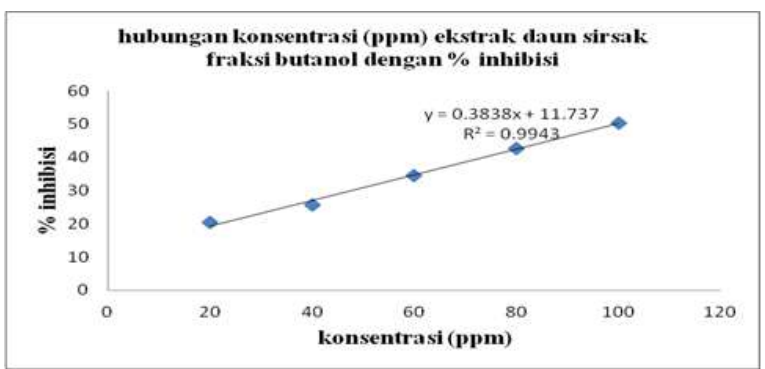

Gambar 4. Hubungan Konsentrasi Ekstrak Daun Sirsak Fraksi Butanol dengan Persen Inhibisi.

Berdasarkan pengujian diperoleh hasil pada gambar 6. diperoleh persamaan $\mathrm{Y}=$ $0.4052 \mathrm{x}+18,872$ sehingga nilai $\mathrm{IC}_{50}$ ekstrak daun sirsak fraksi butanol dapat diketahui yaitu sebesar 99,70 ppm. Aktivitas antioksidan fraksi air lebih baik dibandingkan fraksi butanol.

e. Uji Aktifitas Antioksidan Kombinasi Ekstrak Sarang Semut : Ekstrak Daun Sirsak (1:1)

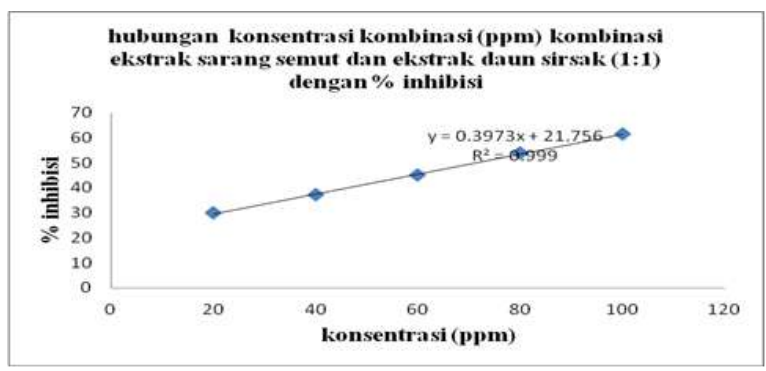

Gambar 5. Hubungan Konsentrasi Kombinasi Ekstrak Sarang Semut : Ekstrak Daun Sirsak (1:1) dengan Persen Inhibisi 
Kombinasi ekstrak sarang semut dan ekstrak daun sirsak (1:1) dibuat berbagai konsentrasi yaitu : 20, 40, 60, 80, 100 ppm. Berdasarkan hasil percobaan diperoleh persamaan regresi linier $\mathrm{y}=$ $0,3973 \mathrm{x}+21,756$, maka dapat diketahui nilai $\mathrm{IC}_{50}$ nya yaitu sebesar $71,09 \mathrm{ppm}$.

Hasil pengujian aktivitas antioksidan kombinasi ekstrak sarang semut dan ekstrak daun sirsak (1:1) memiliki aktivitas antioksidan yang lebih baik jika dibandingkan dengan aktivitas antioksidan ekstrak sarang semut fraksi air, ekstrak sarang semut fraksi butanol, ekstrak daun sirsak fraksi air, dan ekstrak daun sirsak fraksi butanol. Hal ini dibuktikan dengan nilai $\mathrm{IC}_{50}$ kombinasi ekstrak sarang semut dan ekstrak daun sirsak (1:1) sebesar 71.09 ppm, nilai ini lebih kecil dari nilai $\mathrm{IC}_{50}$ ekstrak dalam bentuk tunggalnya. Ekstrak sarang semut fraksi air memiliki IC 50 76,64 ppm, ekstrak sarang semut fraksi butanol memiliki IC $_{50} 76,82 \mathrm{ppm}$, ekstrak daun sirsak fraksi air memiliki $\mathrm{IC}_{50} 73.48$ ppm, sedangkan ekstrak daun sirsak fraksi butanol memiliki IC $\mathrm{I}_{50} 99,70 \mathrm{ppm}$.

\section{f. Uji Fitokimia}

Uji kualitatif fitokimia dilakukan untuk mengetahui kandungan senyawa sampelekstrak sarang semut dan ekstrak daun sirsak yang diduga memiliki aktivitas antioksidan.Uji fitokimia yang dilakukan meliputi uji alkaloid, uji flavonoid, uji terpenoid, uji saponin dan uji tanin.

Uji alkaloid dengan penambahan pereaksi Bouchardat menunjukkan hasil positif karena terbentuk endapan coklat, dengan pereaksi dragendorff juga menunjukkan hasil positif dengan terbentuknya warna jingga, dengan pereaksi mayer juga menunjukkan hasil positif dengan menunjukkan endapan putih kekuningan, dengan pereaksi wagner juga menunjukkan hasil positif dengan terbentuk endapan coklat.

Uji flavonoid menunjukkan hasil positif dengan terbentuk warna merah muda setelah penambahan serbuk seng dan $\mathrm{HCl} 2 \mathrm{~N}$. Hasil positif juga ditunjukkan dengan warna hitam setelah penambahan $\mathrm{HCl}$ dan $\mathrm{FeCl}_{3}$ dan warna hijau kekuningan setelah penambahan $\mathrm{H}_{2} \mathrm{SO}_{4}$.

Uji terpenoid dengan penambahan pereaksi Liebermann - Bouchard menunjukkan hasil negatif tidak terbentuk warna ungu atau merah yang berubah menjadi biru ungu atau biru hijau.Hasil yang terbentuk adalah warna kuning jernih.

Uji Saponin menunjukkan hasil positif dengan terbentuknya busa yang stabil setelah penggojogan bahkan setelah didiamkan dalam posisi tegak selama 10 menit dan dengan penambahan $\mathrm{HCl} 2 \mathrm{~N}$.

Uji Tanin menunjukkan hasil positif dengan terbentuknya endapan setelah penambahan gelatin $1 \%$.Uji penegasan juga menunjukkan hasil positif denganterbentuk warna hijau kecoklatan setelah penambahan $\mathrm{FeCl}_{3}$.

\section{KESIMPULAN DAN SARAN}

Dari hasil penelitian yang sudah dilakukan dapat diambil kesimpulan sebagai berikut:

1. Tumbuhan Sarangsemut dan daun sirsak mengandung alkaloid,flavonoid, tannin dan saponin

2. Fraksi air sarangsemut mempunyai IC 50 sebesar 76,64 ppm sedang fraksi butanol sebesar 76,82 ppm

3. Kombinasi ekstrak sarang semut dan ekstrak daun sirsak (1:1) mempunyai IC50 sebesar 71,09 ppm.

4. Fraksi air daun Sirsak mempunyai IC50 73,48 ppm sedang fraksi butanol memiliki IC I $_{5}$ 99,70 ppm sehingga fraksi air lebih baik dibandingkan fraksi butanol.

5. Kombinasi ekstraks sarang semut dengan daun sirsak dengan perbandingan 1:1 memiliki aktifitas antioksidan lebih baik dari bentuk tunggalnya. 


\section{REFERENSI}

Anoymous, IC50,

http://en.wikipedia.org/wiki/IC50

. Diakses pada tanggal 5 Februari 2010.

Belleville-Nabet, F. 1996. "Zat Gizi

Antioksidan Penangkal Senyawa Radikal Pangan dalam Sistem Biologis." dalam: Prosiding Seminar Senyawa Radikal dan Sistem Pangan: Reaksi Biomolekuler, Dampak terhadap Kesehatan dan Penangkalan. CFNSIPB dan Kedutaan Besar PrancisJakarta.

Demple, B. dan L. Harrison. 1994. Annual Review Biochemistry. 63: 915-948.

Friedberg, E. C., G. C. Walker, dan W. Siede. 1995. DNA Repair and Mutagenesis American society and Microbiology. Washington DC.

Harborne, J. B. 1987. Metode Fitokimia Penuntun Cara Modern Menganalisa Tumbuban.Alih Bahasa: K. Padmawinata. ITB: Bandung.
Hidaka, K., Matsuda, T. and Takea, T. 1999. "chemical studies on Antioxydant Mechanism of Curcuminoid: Analysis of Radical Reaction products from Curcumin, Jurnal Agriculture and Food Chem, Vol. 47.

McCord, J. M. 1979. "Superoxide, Superoxide Dismutase and Oxygen Toxicity." dalam: Reviews in Biochemical Toxicology. E. Hodgson, J. R. Bend, R.M. Philpot (Eds.). Elsevier Amsterdam, the Netherlands. p. 109-124.

Subroto, Ahkam dan Hendro, S. 2008. Gempur Penyakit dengan Sarang Semut. Penebar Swadaya: Jakarta.

Soeksmanto,A 2010, Pakistan Journal of Biological Science 13 (3) :I 48151,2010

Winarsi, H. 2007. Antioksidan Alami dan Radikal Bebas Potensi dan Aplikasinya dalam Kesehatan. Kanisius: Yogyakarta. 